NBER WORKING PAPER SERIES

\title{
REFORMING CONFORMING LOAN LIMITS: THE IMPACT \\ ON THRIFT EARNINGS AND TAXPAYER OUTLAYS
}

\author{
Patric H. Hendershott \\ James D. Shilling
}

Working Paper No. 3010

\author{
NATIONAL BUREAU OF ECONOMIC RESEARCH \\ 1050 Massachusetts Avenue \\ Cambridge, MA 02138 \\ June 1989
}

We are grateful to Edward Kane for his comments on an earlier draft. This research is part of the NBER's research program in Financial Markets and Monetary Economics. Any opinions expressed are those of the authors and not of the National Bureau of Economic Research. 
NBER Working Paper \#3010

June 1989

\title{
REFORMING CONFORMING LOAN LIMITS: THE IMPACT ON THRIFT EARNINGS AND TAXPAYER OUTLAYS
}

\begin{abstract}
In recent years, the conforming loan limit has risen rapidly $(62$ percent between 1985 and 1989 versus a 10 percent rise in the price of a constantquality new house) and has assumed significant importance to homebuyers and portfolio lenders. Fannie Mae and Ereddie Mac have become the price setters for conforming FRMs, and the yield being set appears to be 30 basis points below what it would otherwise be. The lcwer yield raises the old issue of overinvestment in housing, but its most important effect is on thrifts who now earn 30 basis points less on FRM investments under the conforming limit and who have difficulty originating ARMs. Moreover, given other thrift problems, taxpayers will apparently end up directly funding the interest income lost owing to low yields on conforming FRMs.

In this paper we calculate the impact on thrift interest income of two redefinitions of conforming loans: makir.g all refinancings nonconforming and lowering the loan limit to the loan ceiling for FHA/VA loans (which was, in fact, the conforming limit prior to 1975). Each of these redefinitions makes sense from a public policy perspective. Thrifts would have earned nearly $\$ 700$ milion more in 1987 had both redefinitions been in place at the start of 1986 . This would have amounted to a 23 percent increase in the industry net operating income (income excluding profits of losses from the sale of assets) and a corresponding increase in return to equity. By the early 1990s, the income gain from these changes, had they been put in place in early 1986, would likely be over a billion dollars -- certainly a noticeable saving for taxpayers.
\end{abstract}

Patric H. Hendershott Faculty of Finance Ohio State University 321 Hagerty Hal1 1775 College Road Columbus, Ohio 43210 (614) 292-0552
James D. Shilling

Department of Finance

Louisiana State University

Baton Rouge, Louisiana 70803

(504) $388-6255$ 
Any loan under $\$ 187,600$ is classified as conforming in 1989, and only conforming loans can be purchased by the Federal National Mortgage Association (Fannie Mae) and Federal Home Loan Mortgage Corporation (Freddie Mac). Given a 62 percent rise in the conforming limit since 1985, over 90 percent of all conventional fixed-rate mortgage originations are eligible for purchase/securitization by Fannie Mae and Freddie Mac. And securitize them the agencies have. Since 1986, half of the dollar volume of eligible fixed-rate loans have been securitized, up from a twentieth prior to 1982 and a sixth in 1983-84 (Hendershott and Shilling, 1989).

Whether a loan is conforming or not has become significant to homebuyers and portfolio lenders (as well as Fannie Mae and Freddie Mac) because coupon rates on conforming fixed-rate mortgages (FRMs) have declined by about 30 basis points relative to those on otherwise comparable nonconforming FRMs (see Section III below). These lower rates appear to be the result of Fannie and Freddie being able to raise capital market money cheaper than traditional portfolio lenders can and to package mortgages less expensively than private sector mortgage securitizers can. In the 1980s, traditional lenders have lost any cost advantages attributable to tax incentives and deposit rate ceilings; in fact, they are now paying premium costs owing to the FSLIC crisis. 1

Low home mortgage rates are good for recipients of such rates but are bad for other households -- for renters and owners not getting the low rates. A lower mortgage rate would raise homeownership and the quantity of housing, consumer durables, and other capital demanded by homeowners (Meltzer, 1974). The increased demands by the subsidized homeowners, like the tax subsidy for 
homeownership, raise interest rates generally, partially offsetting the ownership subsidy and resulting in higher required returns and eventually less rental housing and industrial plant and equipment. Rents will be higher, and labor productivity and thus wages will be lower.

The subsidized home mortgage rates are also bad for traditional mortgage portfolio lenders both because interest income is lower and because households are less likely to choose ARMs that pay lenders a more competitive yield and provide them with a better asset/liability maturity match. Given the precarious state of the thrift industry and the FSLIC insurance fund, what is bad for traditional portfolio lenders is also bad for U.S. taxpayers generally. ${ }^{2}$ That is, here we have a case where at least some of the costs of an indirect subsidy are showing up explicitly in budgeting deficits.

The ostensible rationale for below-market mortgage rates is to increase homeownership opportunities for Americans. However, while moderate income households may need a subsidy to achieve ownership, upper middle and high income households do not. Moreover, households who own the house they are living in by definition do not need an additional subsidy to own the house. One might think, then, that conforming loans would be defined as loans only for the purchase of houses and only for houses priced below, say, 80 percent of the price of houses in a given area demanded by households with the national median real income.

The actual conforming loan definition does not vary regionally, but it is indexed to median house prices (Lea, 1987). More important from our perspective, the actual definition is far more inclusive than the optimal one. In 1987, 85 percent of the FRM dollar volume and over 90 percent of the number of loans were conforming. That is, the subsidy is received by the vast 


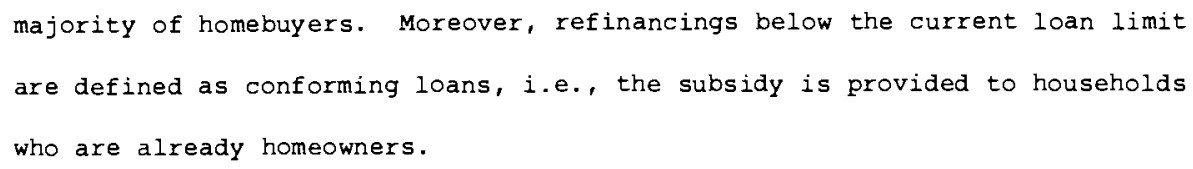

The present paper considers two definitional changes that would have narrowed the subsidy by targeting it more closely to households needing assistance to achieve homeownership. We compute estimates of how these redefinitions would have influenced both the dollar volume of conforming loans originated by saving and loans in eight broad regions of the United States in 1986 and 1987 and the interest earned by holders of the mortgages originated in those regions. We then go on to examine the likely consequences of these changes for the FSLIC insurance fund and thus U.S. taxpayers. The two definitional changes are: a substitution of the FHA/VA loan ceilings in 1986 and 1987 for the actual 1986 and 1987 conforming limits and a blanket classification of refinancings as nonconforming. The first redefinition is only illustrative of more reasonable loan limits; the ideal setting of the general level of the limit and regional variations about it is a complicated issue beyond the scope of this study. We do note, however, that the conforming limit equalled the FHA limit prior to 1975 .

The paper is divided into five sections and a conclusion. Section I indicates the eight regions analyzed, lists median house prices, percentages of loan dollar volume over the conforming limit, and total dollar volume of FRMs originated in the eight regions, and provides estimates of how the alternative conforming loan definitions, alone and in combination, would have affected conforming loan dollar volume in the eight regions. Evidence on the agencies impact on conforming FRM rates is summarized in Section II, and the effect of 
lower FRM rates on the interest income of FSLIC-insured thrifts in the eight regions is reported in Section III. Possible biases in our calculations are discussed in section IV, and our conclusions are stated in section $V$.

II. Alternative Conforming Loan Definitions and Regional Conforming Loan Volumes We have divided the United States into eight contiguous regions based upon the 1987 state proportions of FSIIC-insured-thrift fixed-rate conventional loan volume that were below the conforming limit (see Figure 1). These proportions, which are based on loans financing home purchases (not refinancings), are from the FHLBB monthly loans-closed survey. The high house price (low conforming loan volume) areas are the coastal regions -California-Nevada, the Mid-Atlantic, and the Northeast, where 1987 median house prices financed by conventional savings-and-1oan originated FRMs ranged from $\$ 133,000$ to $\$ 155,000$ (see Table 1 ). Cf the other regions, only the Northwest plus Mountains had a median price above $\$ 90,000(\$ 102,000)$.

The median price of houses financed by FSIIC-insured-thrift FRM originations increased rapidly between 1985 and 1987 (see Table A) in the Northwest ( 31.6 percent), Northeast (34.0) and MidAtlantic (39.4) and moderately elsewhere ( 15.5 to 22.0 percent). However, the national median loan size for FRMs originated by FSLIC-insured thrifts fell slightly because borrowers in high-priced regions shifted to financing with ARMs. The national median price of houses financed by both FRM and ARM conventional originations of all lenders increased by 31.1 percent.

Because the conforming limit rose by a third between 1985 and 1987 when the average FRM loan size was constant, the proportion of FRM dollar volume that was conforming increased from 79 to 85 percent nationwide. Regionally, the increase was greatest in California-Nevada (16 percentage points) and was also large ( 8 percentage points) in the Northwest and Mountains and the Western 
Upper Midwest. By 1987, over 70 percent of loan dollar volume in the highest priced California-Nevada area was conforming, and in the noncoastal regions over 90 percent of this volume was conforming 98 percent in the western Upper Midwest). Table 1 also indicates the percentage of loan volume that was less than 67 percent of the conforming limit. For the country as a whole, this percentage increased from 50 to 59 between 1985 and 1987.

The last column in Table 1 lists the 1987 average regional FHA limits. As can be seen, the difference between the highest and lowest limits is $\$ 20,000$ or only 25 percent of the nationwide mean. This contrasts with a $\$ 95,300$ difference between the average 1987 house prices financed by conventional FRM loans in the highest and lowest cost regions, which is 89 percent of the nationwide mean. ${ }^{3}$ This greater proportionate difference could reflect a larger variation in regional average real incomes (the coastal areas having the highest), as well as variation in costs of constant quality houses.

Table 2 contains our estimates of conventional FRMs originated by FSLICinsured thrifts in 1986 and 1987. We begin with all conventional loans originated to finance home purchases (from the Thrift Quarterly Financial Reports) and scale this down (multiply it) by the fraction of these loans that was fixed rate (from the monthly survey discussed above). To this we add refinancings (all presumed to be FRMs) to obtain total FSLIC-insured thrift FRM originations. ${ }^{4}$ By these estimates, the vclume was $\$ 200$ billion in 1986 and $\$ 150$ billion in 1987 . The higher number in 1986 was largely the result of 70 percent of originations carrying fixed rates in that year versus only 44 percent in 1987 . The shift away from fixed rate financing was especially great (the FRM share dropped by over 25 percentage points) in California-Nevada, the Northeast, the Southeast, and the Northwest and Mountains. 
Table 3 gives the impact on conforming loan volume of lowering the limit to the FHA limits. The reduction would have shrunk the conforming loans market by 49 percent in 1986 and 58 percent in 1987. As a result, the conforming percentage of dollar loan volume in 1987 would have been 35 rather than the observed 85 . On a regional basis, the decline would have exceeded two-thirds in California-Nevada, the Northeast, and the Mid-Atlantic, but would have been less than two-fifths in the two Upper Midwest regions.

Table 4 lists the impact of redefining all refinancings as nonconforming. In 1986 and 1987, total conforming volume would have been 40 to 45 percent less than that recorded. Regionally, the largest percentage decline would have occurred in California-Nevada because that's where refinancings were the heaviest relative to home-purchase loan volume. With this change, the conforming share of the FRM market would have declined from 80 to 50 in 1986 and 85 to 45 in 1987 .

Table 5 shows the combined impact of the two redefinitions. As can be seen, the conforming loan market would have been only one-third (1986) or onequarter (1987) its observed size. All regional declines exceed one-half in both 1986 and 1987, and the percentage decline in California-Nevada would have exceeded 85 in 1986 and 1987. With these redefinitions, the nonconforming loan volume would have tripled in 1986 (from 22.2 percent to 73.2 percent) and more than quintupled in 1987 (from 15.3 percent to 78.9 percent).

II. The Expanded Role of the Agencies and FRM Yields Coupon rates on conforming fixed-rate mortgages have declined in recent years relative to those on otherwise comparable nonconforming FRMs. To illustrate this, we have computed the average effective rates on loans of increasing size (percent of the conforming loan limit) with similar loan-tovalue ratios (75 to 80 percent) originated in California in the May-June period 
of 1978, 1985, 1986 and 1987. California was chosen because it accounts for roughly a quarter of the dollar value of all conventional FRMs closed in the U.S. and over half of all jumbo loans (those over the conforming limit). The data are listed in Table 6 with loan size varying from under 50 percent of the conforming 1 imit up to over 145 percent. The number of loans in the samples and the percent of the eligible dollar volume securitized by Fannie and Freddie are reported at the bottom (see Hendershott and Shilling, 1989, for more detail on the loan samples and the volume securitized).

In general, we would expect the loan rate to decline with loan size because the costs of originating and servicing loans per dollar of loan decrease as the loan size increases. This is clearly the case for loans below the conforming limit in all years except 1985, where the limited number of observations results in much noise in the averages. Of most interest, though, is what happens to the loan rate when the loan size increases above the conforming limit. Prior to 1986, the loan rate is either flat (1978) or still decreasing (1985). But in 1986 and 1987, the loan rate jumps at, or just above in 1987, the loan limit. That is, rates on loans below the loan limit are noticeably less than those above the limit. The most likely cause of this is the expanded activities of Fannie and Freddie; between 1981 and 1986 the percentage of the dollar volume of loans eligible for agency securitization that was securitized rose from 4 to over 50, and the agencies became the market price setters. These activities also likely influence rates on loans just above the limits because such loans will be conforming within a year (Woodward, 1988). Thus the low value for loans 100 to 115 percent of the limit in 1987 may not be as anamolous as it first appears.

In our earlier paper, we estimated, separately for 1978 and 1986, the relationship between rates on loans closed and the loan-to-value ratio, loan size, the precise month the loan was closed, and dummies for geographic regions 
in the state and whether the loan was on a new property, was under the conforming limit, or was just above the limit. The loan-to-value ratio had the expected positive effect, the loan size and the new property dumm the expected negative effects, and the responses of the loan rate to these variables were remarkably similar in the two years. The loan-limit effects were not similar in the two years. In 1986, conforming loans had a 30 basis point lower rate than well-above-the-limit loans had and soon-to-be conforming loans had a 15 basis point lower rate (standard error of only 5 basis points). In 1978, however, the point estimate for the conforming loan coefficient was only 3 basis points.

III. Alternative Conforming Loan Definitions and Thrift Interest Income Owing to the 30 and 15 basis point, respectively, lower yields on conforming and soon-to-be conforming loans, increases in nonconforming loans at the expense of both conforming and soon-to-be conforming loans would raise the interest income of traditional mortgage portfolio investors. To illustrate, if the loan limit had been constant in 1986, rather than increasing 15 percent from $\$ 115,000$ to $\$ 133,000$, investors' interest income would have altered in two ways. First, an extra 30 basis points would have been received on 1986 loans between $\$ 115,000$ and $\$ 133,000$. Second, an extra 15 basis points would have been earned on loans between $\$ 133,000$ and $\$ 153,000$ because originators would have expected these loans to become conforming within the next year under the previous method of indexation and competition would have forced yields down in anticipation of the future lower required yield.

The changes in conforming loan volume shown in Tables 3-5 are translated into changes in FSLIC-insured thrift interest income in Tables 7-9. Each of the tables contains, for 1986 and 1987 separately, the change in conforming- 
loan volume, in just-above-the-conforming-limit volume, and in interest income as a result of replacing conforming loan volume with nonconforming volume. The change in interest income is computed as

$\Delta \mathrm{INC}=.0030 \Delta$ Conforming Volume $+.0015 \Delta$ Just-Above-Limit Volume.

The data for 1987 are cummulative. That is, the change in interest income is based upon greater interest income earned on FRMs originated in both 1986 and 1987. These calculations assume that the originators would have retained the additional nonconforming loans (or sold them to other thrifts in the same region). The calculations also assume no expected increase in FHA limits in either 1986 or 1987.5

A general shift to the FHA/VA limits (Table 7) would have saved FSLICinsured thrifts $\$ 250$ million in $1986, \$ 480$ million in 1987 and probably over $\$ 600$ million in $1988 .^{6}$ of the saving, 37 percent would have accrued to California-Nevada thrifts, which accounted for 32 percent of total financing. The smallest saving goes to the Upper Midwest, which originated the fewest mortgages. Less than 5 percent of the saving in Tables 7-9 is attributable to loans just above the old limit.

Redefining all refinancing as nonconforming (Table 8) would have increased FSLIC-insured thrift interest income by $\$ 200$ million in 1986 and $\$ 380$ million in 1987. About a third would have been received by thrifts in California-Nevada; about a tenth each would have accrued to thrifts in the Mid-Atlantic, the Southeast, the Eastern Upper Midwest and the Lower Midwest.

The overall impact of both changes (Table 9) would have raised interest income by $\$ 350$ miliion in 1986 and $\$ 630$ million in $1987 .^{7}$ Again, about a third of the increase would have gone to California, and a tenth to a seventh to the MidAtlantic, Southeast, Eastern Upper Midwest and Lower Midwest. An aggregate estimate for 1988 would be an $\$ 800$ million gain. 
IV. Possible Bias in the Estimates

The data in Tables 7-9 are subject to a number of possible biases. The thrift income gains from redefining refinancings as nonconforming are certainly understated. The volume of loans affected is too high because we assumed all refinancings were FRMs, while some (probably less than 5 percent -- see footnote 4) were ARMs. Further, if loan rates on refinancings had been 30 basis points higher in 1986 and 1987, fewer loans would have been refinanced and thrifts would have saved 150 to 250 basis points per dollar loan not refinanced. Also, valuable servicing contracts would not have been terminated. These savings would swamp the overstatement of savings from classifying some ARM refinancings as FRMs.

We have ignored any impact of lower FRM yields on the ARM market, and this results in an underestimate of the impact of a lower conforming limit on thrift interest income. The agency reduction in FRM yields likely lowered yields on conforming ARMs also. Thus reducing the loan limit to the FHA limit -- raising the yields on FRMs between these limits -- would be expected to raise yields on ARMs between these limits.

Another questionable assumption in the calculation is that thrifts would have either held the new nonconforming FRMs they originated or sold them to other thrifts in the same region. Of course, if the loans had a 30 basis point higher return, thrifts would have been more likely to hold them. To the extent these loans would have been sold to thrifts in other regions, the distribution of interest income gains among regions would be altered. To the extent that these loans would have been sold to nonthrift investors -- or that fewer new (as opposed to refinancing) loans would have been closed, the total interest income gain is overstated. 
The largest bias probably is due to the assumed $30 / 15$ basis point gain. Our 1987 data reveal that the broadest redefinition of nonconforming loans would have increased the nonconforming share of the FRM market from 15 to 79 percent. With a quintupling of this market, private securitizers would expand and gain economies of scale. In time (probably only a year or two), the gain from the redefinitions per dollar of redefined nonconforming loans would likely be reduced to, say, $20 / 10$ basis points. That is, in the longer run only twothirds of the interest gain might be realized.

on the other hand, the dollar volume of loans benefiting from the higher interest rate would continue to grow over time as old loans are repaid and new ones taken out. Even holding the total volume of FRM loans constant, the increases in interest income from the narrower redefinition of conforming loans would probably triple the 1987 estimates. Thus even if the interest savings per dollar of redefined nonconforming loans are only two-thirds of those indicated for 1987 in Tables 7-9, the long-run impacts are probably double those indicated. That is, in three to five years, thrift interest income would be over a billion dollars greater, on the current asset base, if these definitional changes had existed prior to 1986 .

Table 10 indicates the impact of lower conforming loan limits in 1986 and 1987 on thrift net operating income (income excluding profit or loss on sale of assets). The first column contains actual net operating income (NOI), and the next three columns show the percentage increase under the different redefinitions of conforming loans. For the total industry, NOI would have been 14 percent higher if refinancings had been nonconforming in 1986 and 1987, 17 percent higher if the FHA/VA limits had applied to conforming loans, and 23 percent if both redefinitions had been in place. These totals overstate the typical regional impacts, though, because NOI was so negative in the Lower Midwest region. In fact, excluding the oil patch from the calculation lowers 
the percentage increase to just under 10 percent. The typical regional percentage increase in NOI would have been 10 or 11 percent, although the increases for the Northeast and Eastern Upper Midwest are slightly smaller and that for the Northwest plus Mountains is far larger. The latter number is attributable to a - $\$ 222$ million NOI in Alaska, which sharply reduces the denominator in the calculation.

\section{v. Conclusion}

Prior to 1986, the conforming loan limit was not of major importance to homebuyers. While rates on loans below the limit were subject to the discipline of the secondary market, these rates were not systematically lower than rates on larger loans. Moreover, thrifts probably preferred a higher loan limit, especially in the early 1980s, because they could then sell a greater portion of their existing FRM portfolios or at least swap them and use the agency securities as collateral for borrowing. Also, the agencies provided a ready market for FRM sales by thrifts who wished to originate FRMs for sale rather than for portfolio.

In recent years, though, the loan limit has risen rapidly $(62$ percent between 1985 and 1989 versus a 10 percent increase in the price of a constantquality new house) and has assumed far greater importance. The agencies have become the price setter for conforming FRMs, and this yield appears to be set 30 basis points below what it would otherwise be. The lower yield raises the old issue of overinvestment in housing, but its most important effect is on thrifts who now earn 30 basis points less on FRM investments under the conforming limit and who have difficulty originating ARMs. Moreover, given other thrift problems (nonearning assets and a generally high-cost fund raising 
network), taxpayers are ending up directly funding the interest income lost owing to low yields on conforming FRMs. That is, the extraordinary increase in the loan limit is having significant budgetary consequences.

In this paper we consider two redefinitions of conforming loans: making all refinancings nonconforming and lowering the loan limit to the loan ceiling for FHA/VA loans (which was, in fact, the conforming limit prior to 1975). Each of these redefinitions makes sense from a public policy perspective. Subsidized loan rates can be rationalized as a means of assisting those who need assistance to achieve homeownership. The current loan limits are inappropriate because they make subsidized loans available to well over ninety percent of households and they provide a subsidy to refinancers who remain in their already owner-occupied dwellings. Of course, an increase in home mortgage rates would have a temporary negative impact on the homebuilding, mortgage originating, and home selling industries and thus would likely be opposed by the homebuilders, the mortgage bankers and the realtors.

The estimated impacts of these conforming-loan redefinitions on thrift interest income are large because an enormous volume of loans was originated in 1986 and 1987 when home sales were strong and refinancings were commonplace. Thrifts would have earned $\$ 680$ million more in 1987 had both redefinitions been in place at the start of 1986. This would have amounted to a 23 percent increase in the industry net operating income (income excluding profits of losses from the sale of assets) and a corresponding increase in return to equity. By the early 1990s, the income gain from these changes, had they been put in place in early 1986, would likely be over a billion dollars. The greatest effect of these redefinitions would be on healthy savings and loans because many of the weakest institutions -- those in the oil patch most prominently -- have largely gotten out of traditional residential lending and moved into riskier activities. 
References

Hendershott, Patric H. "The Future of Thrifts as Mortgage Portfolio Lenders," The Future of the Thrift Industry, Proceedings of the Fourteenth Annual Conference, Federal Home Loan Bank of San Francisco, 1989.

Hendershott, Patric H. and James D. Shilling, "The Impact of the Agencies on Conventional Fixed-Rate Mortgage Yields," The Journal of Real Estate Finance and Economics, 1989.

Hendershott, Patric H. and Robert Van Order, "Integration of Mortgage and Capital Markets and the Accumulation of Residential Capital," Regional Science and Urban Economics, 1989.

Kane, Edward, The Gathering Crisis in Federal Deposit Insurance, MIT Press, 1985.

Lea, Michael J., "Housing and the Capital Markets," MIT Center for Real Estate Development, April 1988.

Lea, Michael J., "Raising the Roof: the Loan Limit Controversy," Secondary Mortgage Markets, winter 1986/87, pp. 26-29.

Meltzer, Allan H., "Credit Availability and Economic Decisions: Some Evidence from the Mortgage and Housing Markets," Journal of Finance, June 1974, pp. $763-777$.

Woodward, Susan E., "Policy Issues in the Privatization of FNMA and FHLMC," Expanded Competitive Markets and the Thrift Industry, Proceedings of the Thirteenth Annual Conference, Federal Home Loan Bank of San Francisco, 1988, pp 169-184. 


\section{Footnotes}

1 For a discussion of this point, see Hendershott (1989), Hendershott and Van order (1989), and Lea (1988).

2

For an early analysis of the FSLIC problem, see kane (1985).

3 only median prices are shown in Table 1. The average price varied regionally from a low of $\$ 73,000$ in the Western Upper Midwest to a high of $\$ 168,300$ in California/Nevada. The nationwide median was $\$ 107,000$.

4

Less than 10 percent of the outstanding stock of home mortgages had adjustable rates in 1986, and the refinancing incentive of a decline in interest rates is much stronger for fixed than adjustable rate loans. Thus over 95 percent of refinancings were likely fixed rate.

5 The statutory FHA limits were unchanged between 1980 and 1987, although the effective limit increased moderately because some areas shifted from lower to higher regional limits (minimum of $\$ 67,500$; maximum of $\$ 90,000$ ).

6 This presumes that all loans originated in a year were originated on the first day of the year. A more accurate, but also more awkward, statement would be that 250 milion represents the interest saved in years after 1986, ignoring repayments, owing to the saving on loans originated in 1986.

7 The $\$ 630$ million is a gain from lower loan limits. The gain from a zero loan limit, or the cost to the thrifts of the agencies lowering the FRM rate by 30 basis points, is $\$ 900$ million (all conforming loan volume in 1986 and 1987 times 30 basis points plus the $\$ 13 \frac{1}{2}$ billion just-above the limit times 15 basis points). 


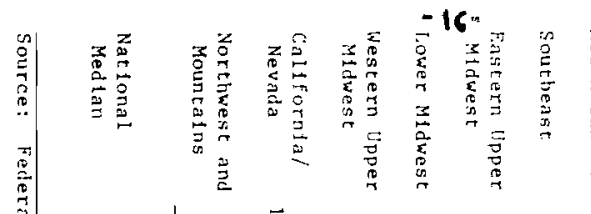

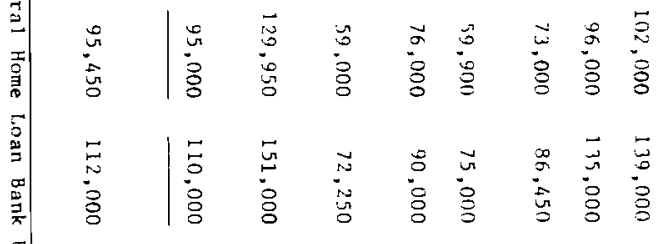

总

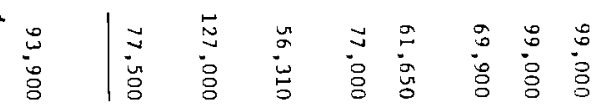

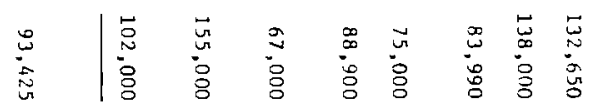

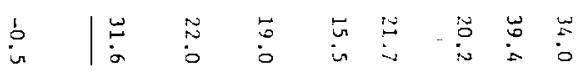

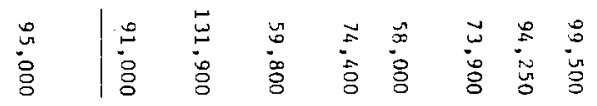

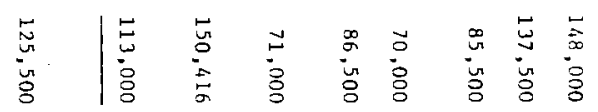

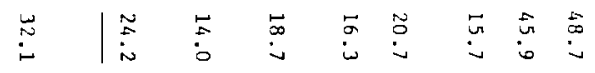

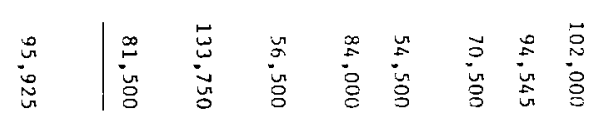

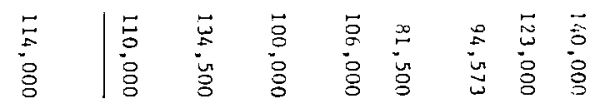

票 |

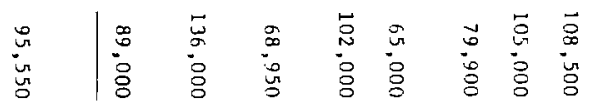

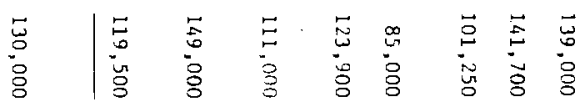

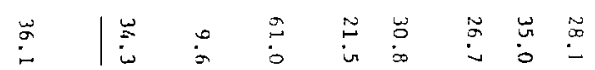

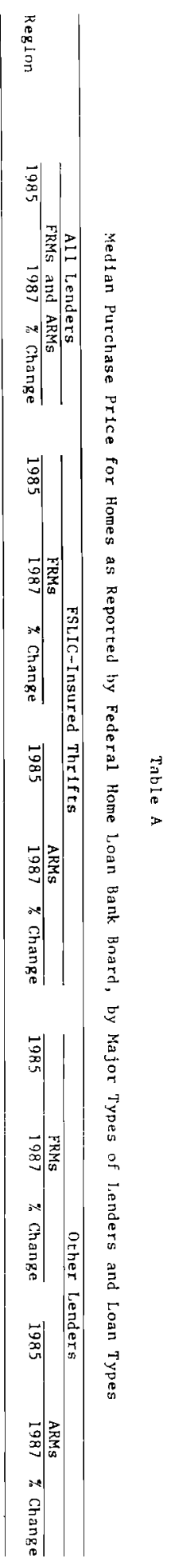



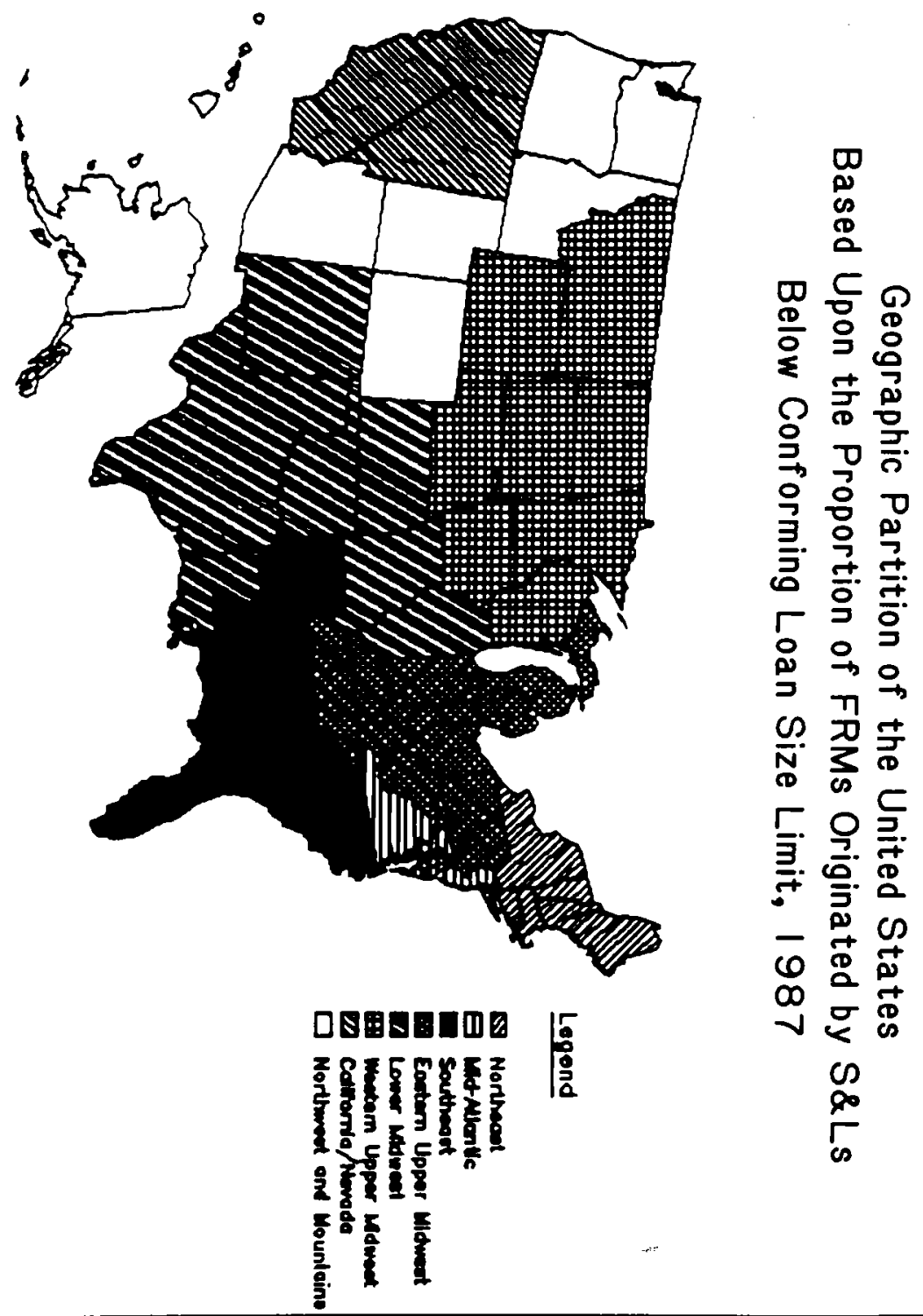


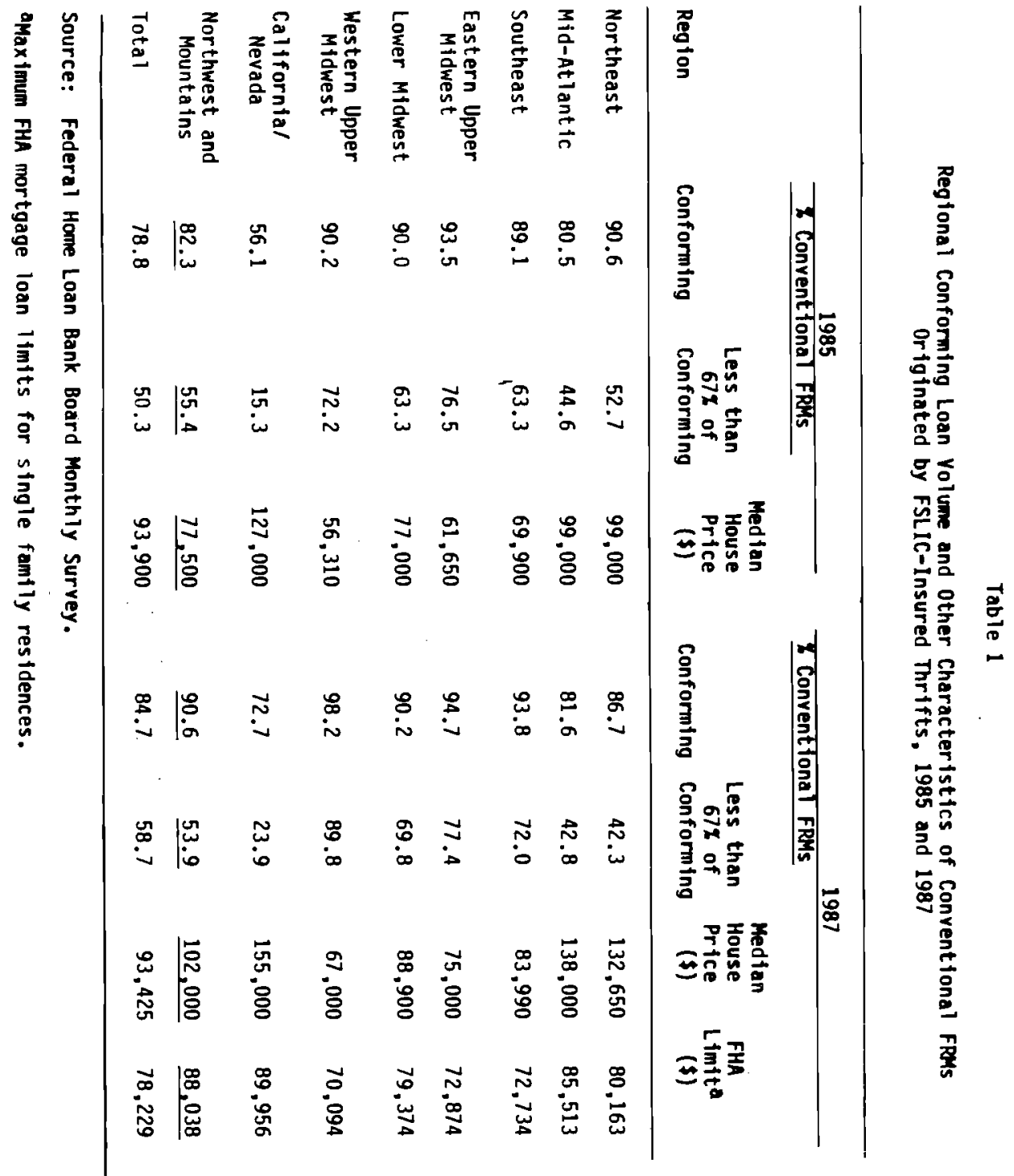




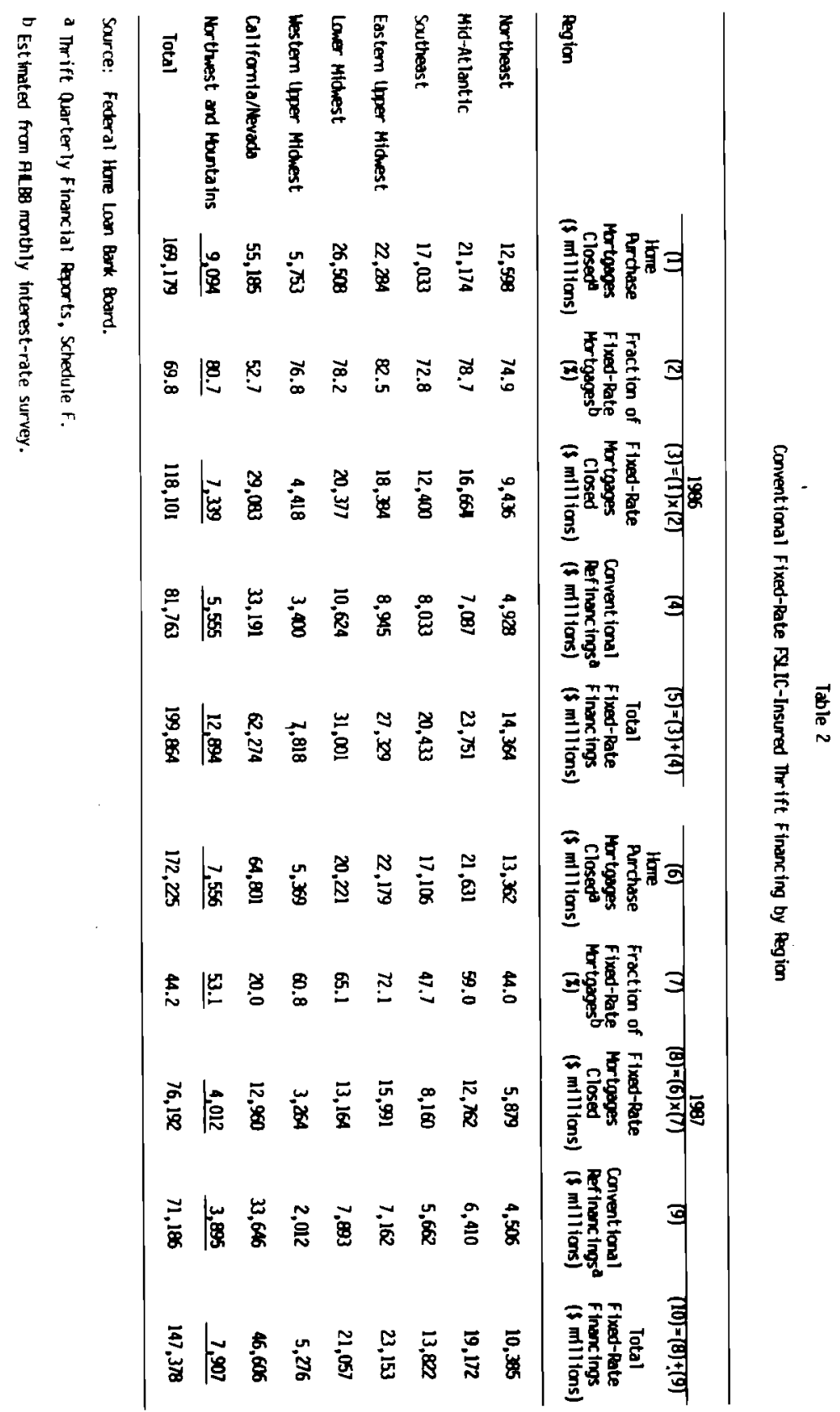




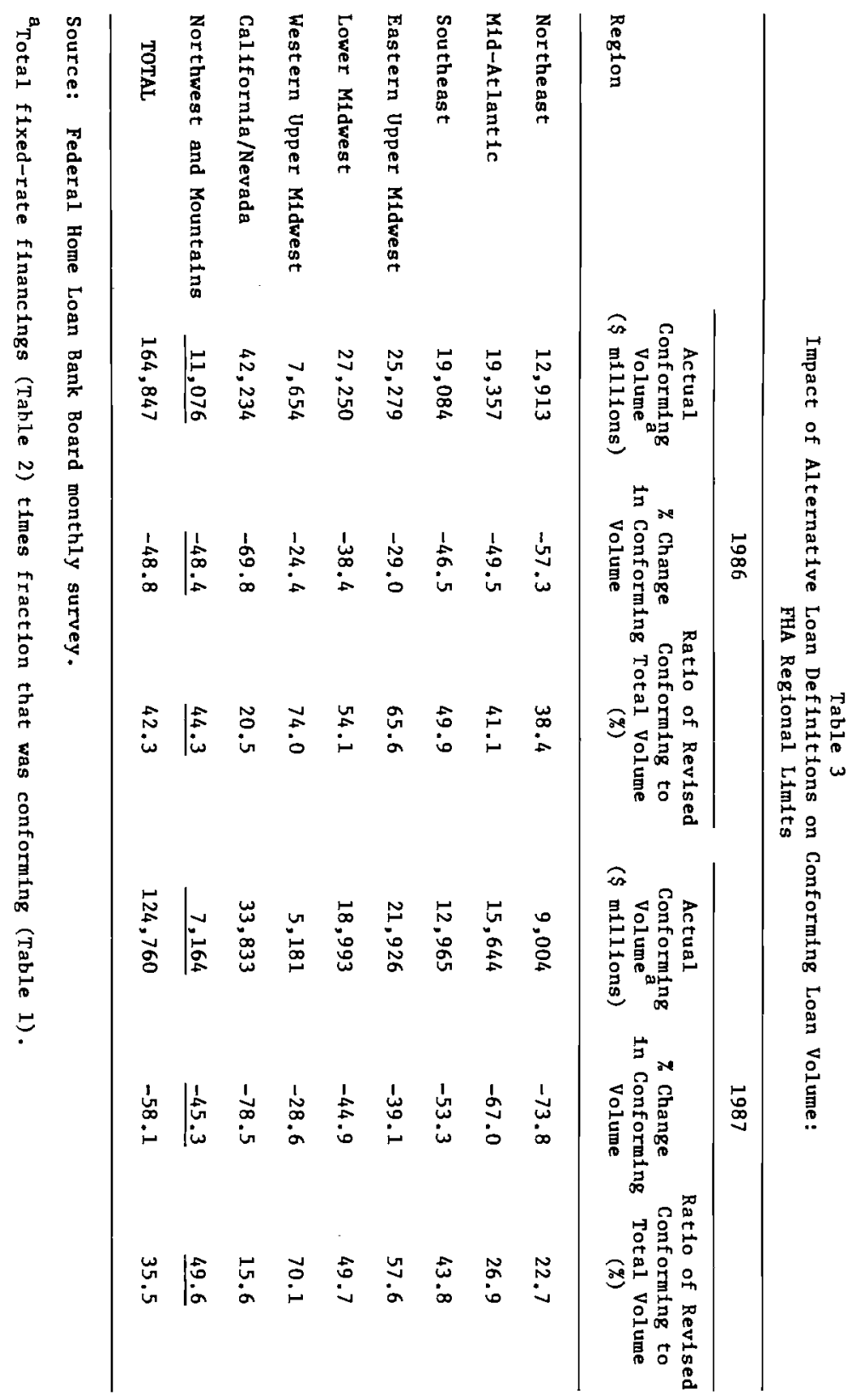




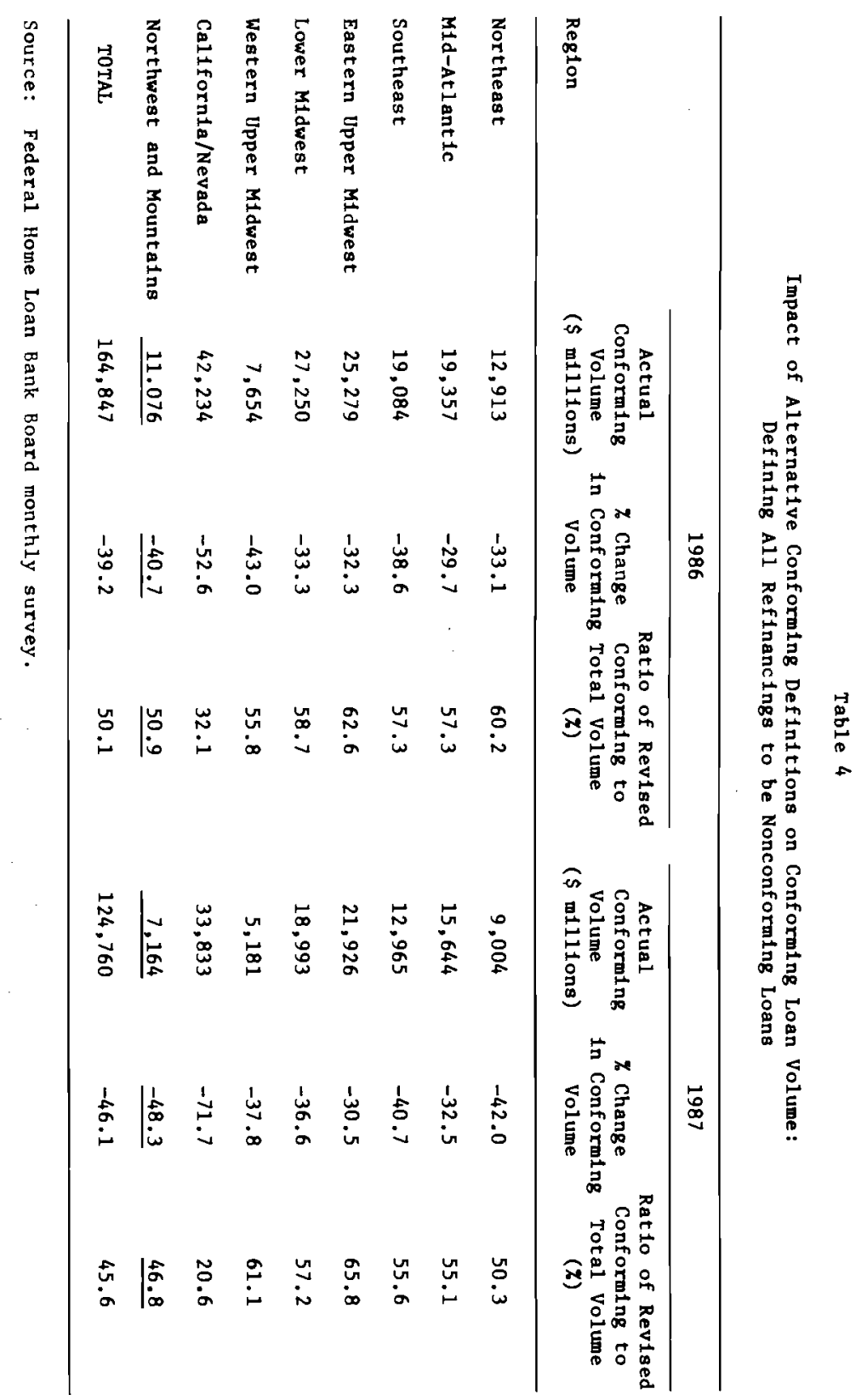




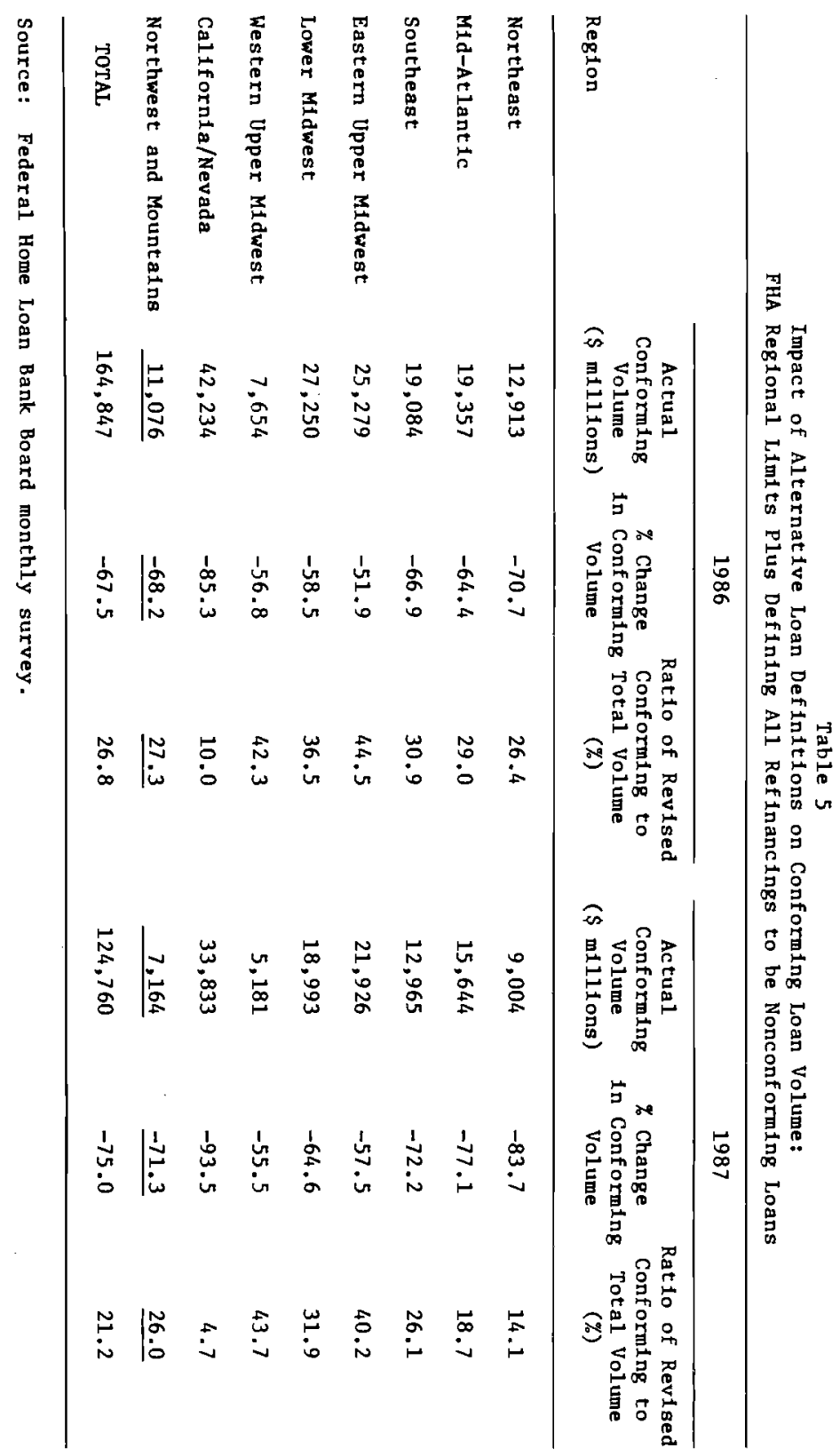


Table 6

Effective Loan Rates for California FRMs with Loan-to-Value Ratios of 75 and 80 Percent by Loan Size, Selected Years

\begin{tabular}{lcccr}
$\begin{array}{l}\text { Percent of } \\
\text { Conforming } \\
\text { Loan Limit }\end{array}$ & 1978 & 1985 & 1986 & 1987 \\
\hline $0.0-50.0$ & 10.12 & 11.75 & 10.65 & 9.83 \\
$50.1-67.0$ & 10.04 & 11.87 & 10.53 & 9.82 \\
$67.1-80.0$ & 9.97 & 11.98 & 10.51 & 9.77 \\
$80.1-90.0$ & 9.97 & 11.66 & 10.40 & 9.63 \\
$90.1-100.0$ & 9.95 & 12.22 & 10.36 & 9.62 \\
------115.0 & 9.94 & 11.13 & 10.62 & 9.63 \\
$100.1-115$ & 9.97 & 11.46 & 10.65 & 9.91 \\
$115.1-130.0$ & 9.95 & 11.39 & 10.68 & 9.80 \\
$130.1-145.0$ & 9.94 & 10.97 & 10.70 & 9.83 \\
Over 145.0 & & & & -
\end{tabular}

Number of

Loans

3,590

710

1,157

1,706

Percent of

Dollar Volume

Securitized

$4 \quad 36$

57

52

Source: FHLBB monthly survey

${ }^{a}$ Conventional FRMs closed in California in May-June of each year Excludes loans originated by mortgage and comercial bankers and combination construction-purchase loans. 


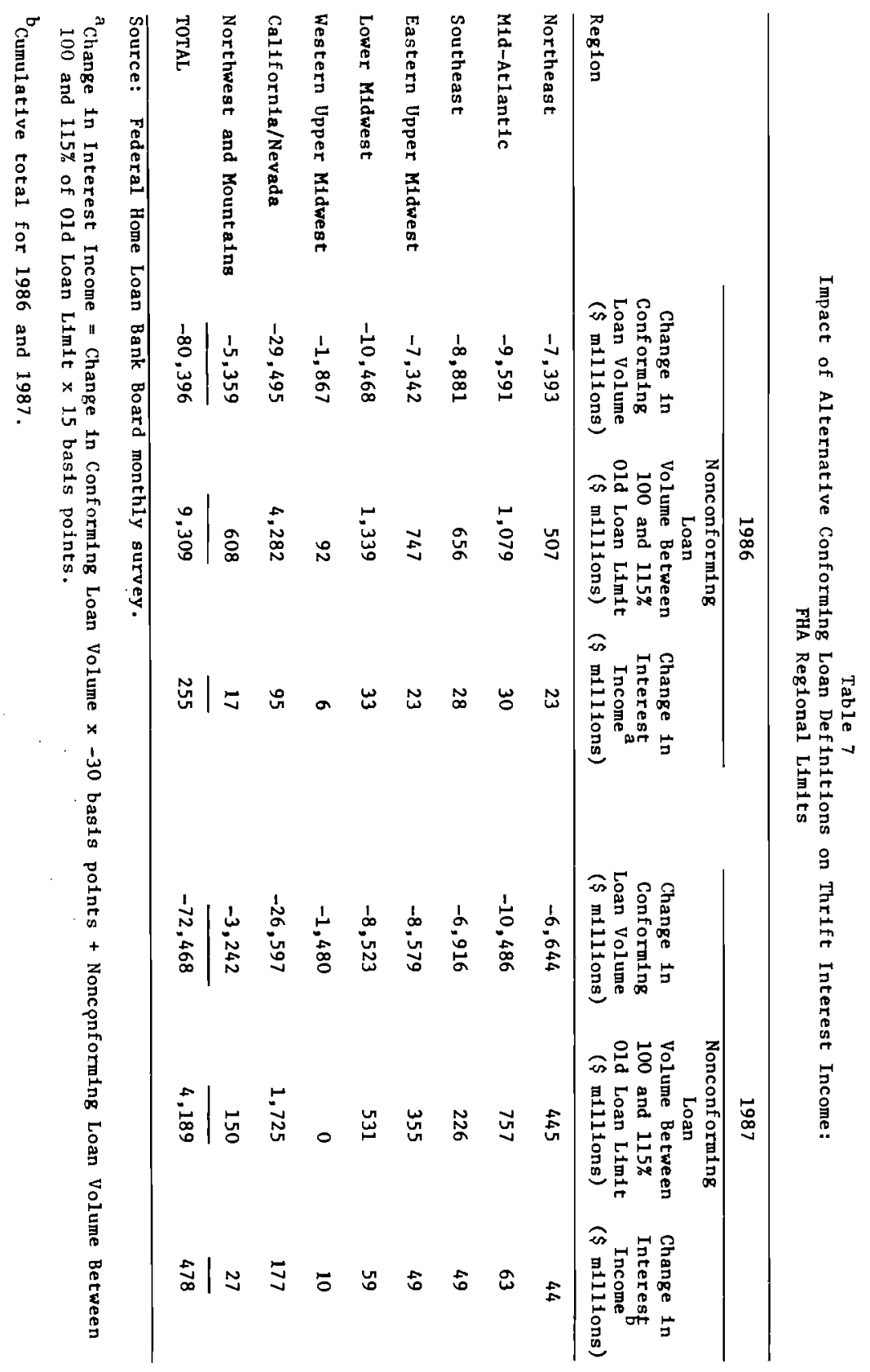




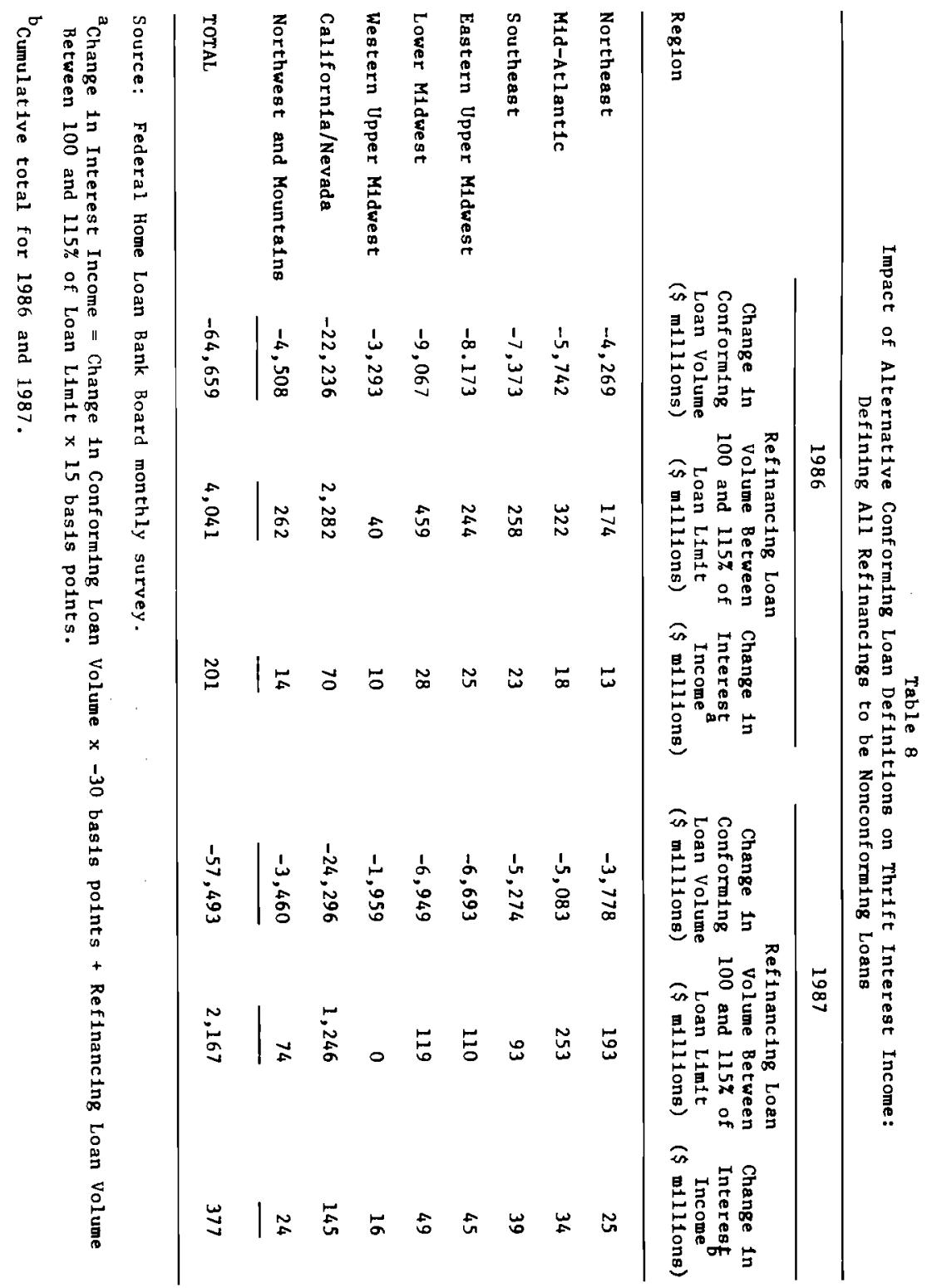




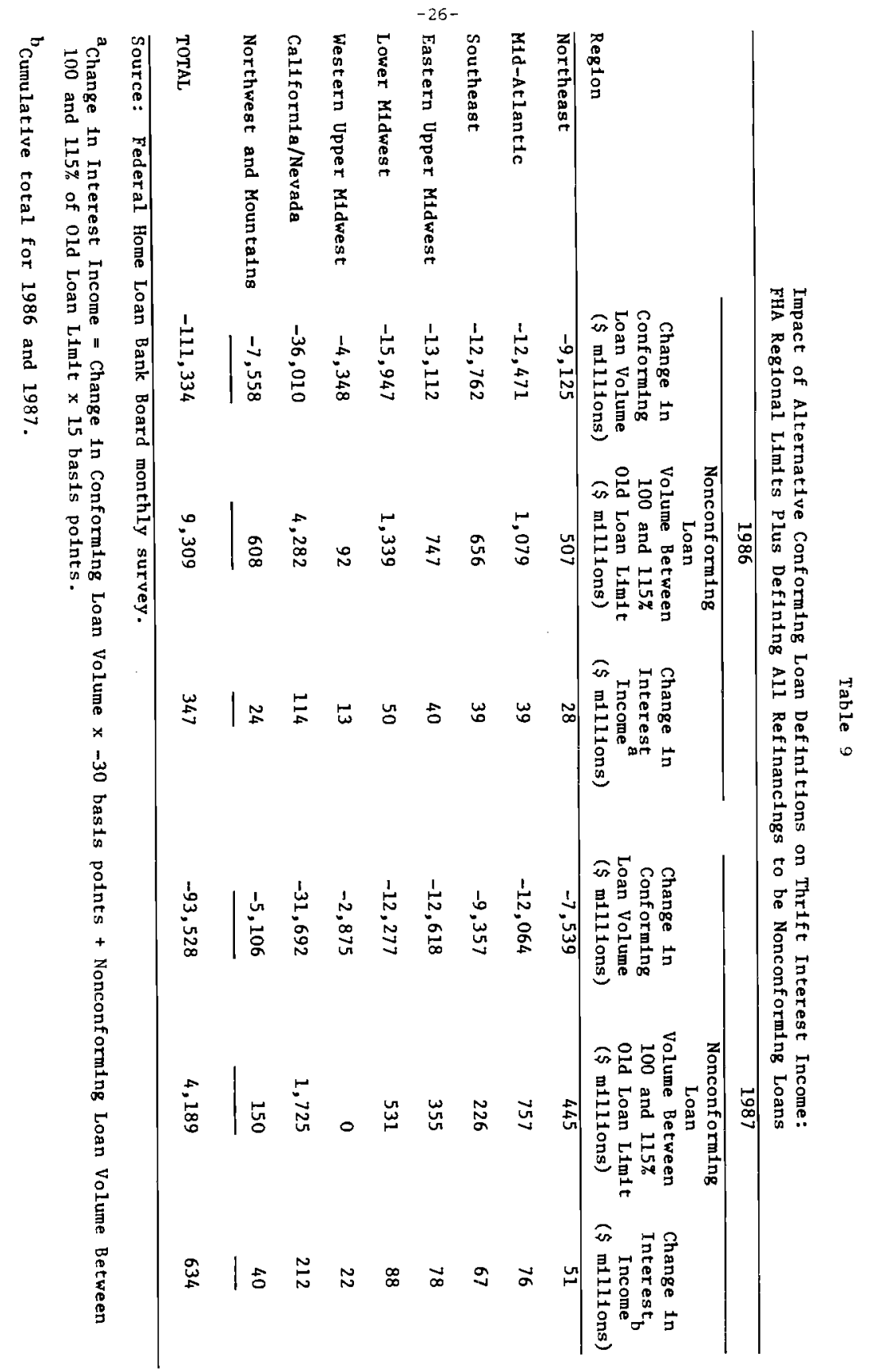


Table 10

Percentage Change in Thrift Net Operating Income Arising

from Alternative Conforming Loan Definitions, 1987

Percentage Change in Net Operating Income FHA Limits

Al1 Plus A11

\begin{tabular}{|c|c|c|c|c|}
\hline Region & $\begin{array}{l}\text { operating } \\
\text { Income } \\
\text { (\$millions) }\end{array}$ & $\begin{array}{c}\text { FHA Regional } \\
\text { Limits }\end{array}$ & $\begin{array}{c}\text { Refinancings } \\
\text { Nonconforming } \\
\text { Loans }\end{array}$ & $\begin{array}{c}\text { Refinancings } \\
\text { Nonconforming } \\
\text { Loans }\end{array}$ \\
\hline Northeast & 683 & 6.44 & 3.66 & 7.47 \\
\hline Mid-Atlantic & 709 & 8.89 & 4.80 & 10.72 \\
\hline southeast & 663 & 7.39 & 5.88 & 10.11 \\
\hline Eastern Upper Midwest & 1,401 & 3.50 & 3.21 & 5.57 \\
\hline Lower Midwest & $-2,891$ & -2.04 & -1.69 & -3.04 \\
\hline Western Upper Midwest & 193 & 5.18 & 8.29 & 11.40 \\
\hline California/Nevada & 1,926 & 9.19 & 7.53 & 11.01 \\
\hline Northwest \& Mountains & 96 & 28.13 & 25.00 & $\underline{41.67}$ \\
\hline TOTAL & 2,779 & 17.20 & 13.57 & 22.81 \\
\hline $\begin{array}{l}\text { TOTAL excluding } \\
\text { Oil Patch }\end{array}$ & 6,280 & 7.29 & 5.78 & 9.63 \\
\hline
\end{tabular}

Source: Federal Home Loan Bank Board

a Net operating income excludes profit or loss on sale of foreclosed real estate, other repossessed property, other real estate held, investment securities, loans and other assets.

b Excludes Texas, Louisiana, Oklahoma and New Mexico, all of which had negative NOI $(\$ 3,339$ million in Texas alone). Two thirds of the interest savings is for the Lower Midwest area assumed to accrue to thrifts outside the oil patch. 